Vol.61: e18180417, 2018

http://dx.doi.org/10.1590/1678-4324-2018180417

ISSN 1678-4324 Online Edition
BRAZILIAN ARCHIVES OF BIOLOGY AND TECHNOLOGY

\title{
Comparative Cytogenetics Among Three Sympatric Hypostomus Species (Siluriformes: Loricariidae): An Evolutionary Analysis in a High Endemic Region
}

\author{
Carla Andreia Lorscheider, ${ }^{1}$ Jordana Inácio Nascimento Oliveira, ${ }^{2}$ Thais Aparecida Dulz ${ }^{1}$, \\ Viviane Nogaroto $^{2 *}$, Isabel Cristina Martins-Santos ${ }^{3}$, Marcelo Ricardo Vicari ${ }^{2}$ \\ ${ }^{1}$ Departamento de Ciências Biológicas, Universidade Estadual do Paraná, União da Vitória, Paraná, Brazil; \\ ${ }^{2}$ Departamento de Biologia Estrutural, Molecular e Genética, Universidade Estadual de Ponta Grossa, Ponta Grossa, \\ Paraná, Brazil; ${ }^{3}$ Programa de Pós-Graduação em Ciências Biológicas, Departamento de Biologia Celular e Genética, \\ Universidade Estadual de Maringá, Maringá, Paraná, Brazil.
}

\begin{abstract}
The karyotypes of three armored catfish species (Loricariidae) from the Iguaçu river, southern of the Brazil, were compared using different techniques: C-banding, Ag-NOR and fluorescence in situ hybridization (FISH), which used $5 S$ and $18 S$ rDNAs and total $C_{o} t-1$ fraction as probes. Hypostomus commersoni and Hypostomus derbyi presented $2 n=68$ chromosomes, with karyotype formulae $12 m+12 s m+14 s t+30 a$ and $12 m+12 s m+10 s t+34 a$, respectively; whereas Hypostomus myersi presented $2 n=74$ chromosomes and $12 m+16 s m+12 s t+34 a$. The chromosomal localization of the Ag-NORs, $5 \mathrm{~S}$ and $18 \mathrm{~S}$ rDNAs differed in number of sites and chromosomal localization among the studied species. The total $C_{o t}$-1 probe permitted the visualization of the repetitive DNA fraction in karyotypes of each species. Crosshybridizations using total $C_{o} t-1$ probe revealed that these species have repetitive DNAs in common. However, this does not occur in $H$. commersoni in relation to the other species. The apparent karyotype similarity suggests a close relationship between the sympatric $H$. commersoni and $H$. derbyi species, but the small differences detected in the examined chromosomal markers indicate evolutionary divergence due to gene flow restriction among them. Hence, the present findings indicate different composition of repetitive sequences among studied species, which permit to infer its role in chromosomal differentiation of Hypostomus.
\end{abstract}

Keywords: Armored catfish; FISH; Iguaçu river; karyotype evolution.

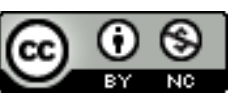

*Author for correspondence: vicarimr@uepg.br 


\section{INTRODUCTION}

The armored catfishes are characterized by a body covered by bony plates and a ventral suckermouth ${ }^{1}$. Loricariidae is the largest family of the Siluriformes, accounting 974 valid species ${ }^{2}$, and has phylogenetic studies that shown constant systematic reallocations in its subfamilies and genus ${ }^{1,3-6}$. The genus Hypostomus Lacépède, 1803 contains the greatest number of species in the Hypostominae subfamily (29 genera in total) ${ }^{1,7-9}$, occurring in various freshwaters ecosystems throughout tropical and subtropical regions in South America ${ }^{1}$.

Hypostomus possesses apomorphic morphological and cytogenetic characters among loricariids ${ }^{10}$, such as broad diploid number (2n) ranging (64 to 84 chromosomes) and, usually, multiple sites of rDNAs ${ }^{11-14}$, while some species have chromosomal characteristics considered to be plesiomorphic in the family, like sinteny in ribosomal genes families ${ }^{10}$. In Hypostomus, karyotype formulae, heterochromatin distribution, and number and localization of rDNAs sites are considered important evolutionary chromosome markers ${ }^{10,15-18}$. Chromosome variability at the intra- and interspecific level are detected in comparative cytogenetic studies ${ }^{16-18}$. In addition, recent cytogenetic data showed that evolutionary breakpoint regions clustered in repetitive DNA regions promoted genomic reshuffle and chromosome evolution in Loricariidae species ${ }^{19-25}$. Iguaçu River is an important tributary of Paraná River basin in the south region of Brazil and presents high endemism of its ichthyofauna due to the isolation caused by the formation of the Iguaçu waterfalls 22 Mya ago ${ }^{26}$. Five species of Hypostomus are described in the Iguaçu River: Hypostomus albopunctatus (Regan, 1908), Hypostomus commersoni Valenciennes, 1836, Hypostomus derbyi (Haseman, 1911), Hypostomus myersi (Gosline, 1947) and Hypostomus nigropunctatus Garavello, Britski \& Zawadzki, 2012 , being $H$. derbyi and $H$. nigropunctatus restricted to this basin ${ }^{27}$. The aim of the present study was to perform cytogenetical analysis in three Hypostomus species $(H$. commersoni, $H$. derbyi, and $H$. myersi) collected in in the middle Iguaçu River region (União da Vitória, Paraná State, Brazil - the type-localization of $H$. derbyi and $H$. myersi description), in order to establish chromosomal characterization among these sympatric and syntopic armored catfishes.

\section{MATERIALS AND METHODS}

Specimens of $H$. commersoni ( 4 females and 4 males), $H$. derbyi ( 3 females and 6 males), and $H$. myersi ( 8 females and 6 males) were collected in the Iguaçu River (Fig. 1), Paraná River Basin, Brazil (26 $15^{\prime} 1.11^{\prime \prime} \mathrm{S}$ and $\left.51^{\circ} 6^{\prime} 10.67^{\prime \prime} \mathrm{W}\right)$. The specimens were identified and desposited in the ichthyologic collection of the Núcleo de Pesquisas em Limnologia, Ictiologia e Aquicultura (Nupélia; acronym = NUP) of Universidade Estadual de Maringá, Brazil (H. commersoni NUP 13581; H. derbyi NUP 13582; H. myersi NUP 13579). The procedures were performed according to the Ethics Committee in Animal Experimentation (Process CEUA 29/2016) of the Universidade Estadual de Ponta Grossa. 


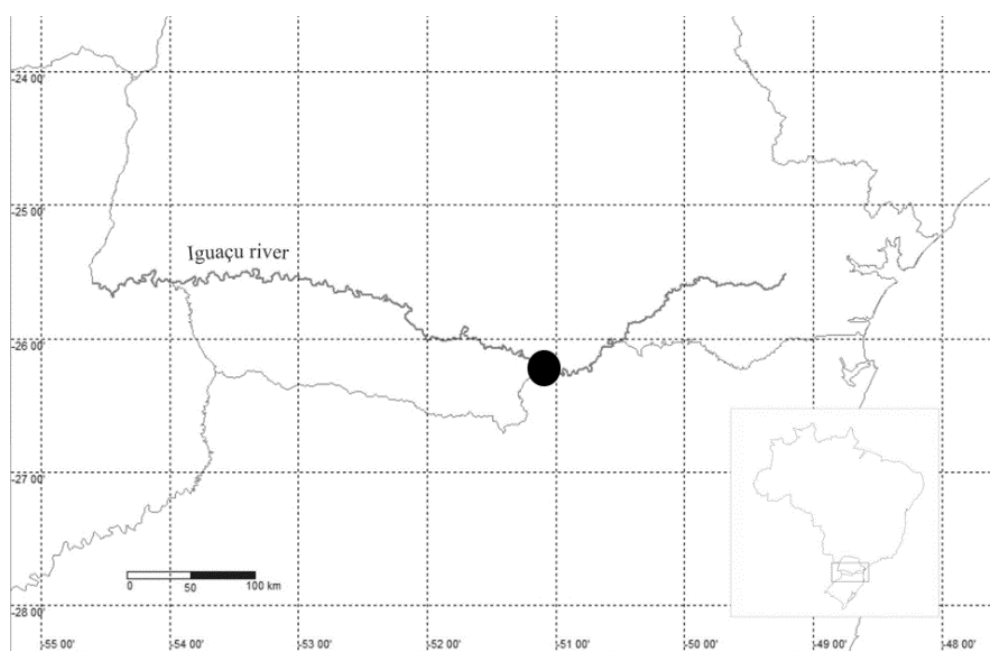

Figure. 1. Map of Brazil, highlighting the state of Paraná and the Iguaçu river drainage. The circle refers to sampled collection region at União da Vitória.

Chromosome preparations were obtained by the air-drying method ${ }^{28}$, and then subjected to conventional Giemsa staining, C-banding for identification of heterochromatin regions 29-30 and silver nitrate impregnation $\left(\mathrm{AgNO}_{3}\right)$ for detection of nucleolar organizer regions (NORs) ${ }^{31}$. Genomic DNA was obtained from liver using cetyltrimethylammonium bromide $(\mathrm{CTAB})$ method ${ }^{32}$. The DNA fraction containing moderately and highly repetitive DNAs was obtained by the $\mathrm{C}_{o} \mathrm{t}-1$ DNA reassociation kinetic technique ${ }^{33-34}$, with modifications ${ }^{35}$. Fragments obtained by $\mathrm{C}_{o} \mathrm{t}-1$ ranged from 100 to $400 \mathrm{bp}$ and were used as probe in cross-fluorescence in situ hybridization (crossFISH) among the Hypostomus species. In addition, FISH experiments were performed using $18 \mathrm{~S}^{36}$ and $5 \mathrm{~S}$ rDNAs ${ }^{37}$ as probes, obtained from each of the three species studied. The probes were labeled by nick translation, using biotin-16-dUTP or digoxigenin-11dUTP, following the manufacturer protocol (Roche Applied Science, Mannheim, Germany).

The general protocol for FISH procedure ${ }^{38}$ was followed under stringency condition $\sim 80$ $\%(2.5 \mathrm{ng} / \mu \mathrm{L}$ probe, $50 \%$ formamide, $2 \mathrm{x}$ SSC - sodium saline citrate -, $10 \%$ dextran sulfate, for $18 \mathrm{~h}$ at $42{ }^{\circ} \mathrm{C}$ ). Post-hybridization washes were performed in high stringency (50\% formamide at $42{ }^{\circ} \mathrm{C}$ for $20 \mathrm{~min}, 0.1 \mathrm{x} \mathrm{SSC}$ at $60{ }^{\circ} \mathrm{C}$ for $15 \mathrm{~min}$, and $4 \mathrm{x}$ SSC $0.05 \%$ Tween at room temperature for $10 \mathrm{~min}$ ). Signal detection was performed using antibodies Streptavidin Alexa Fluor 488 (Molecular Probes, Carlsbad, CA, USA) and antidigoxigenin rhodamine (Roche Applied Science). Chromosomes were counterstained with 4',6-diamidino-2-phenylindole (DAPI $0.2 \mu \mathrm{g} / \mathrm{mL}$ ) in mounting medium Vectashield (Vector, Burlingame, CA, USA) and analyzed using an epifluorescence microscope. Chromosomes were classified according to Levan et al. ${ }^{39}$, like metacentric (m), submetacentric (sm), subtelocentric (st) and acrocentric (a) chromosomes. Fundamental number (FN) considered the $\mathrm{m}$, sm and st chromosomes with two arms and acrocentric chromosomes with one arm. 


\section{RESULTS}

\section{Hypostomus commersoni}

Hypostomus commersoni presented $2 \mathrm{n}=68$ chromosomes $(12 \mathrm{~m}+12 \mathrm{sm}+14 \mathrm{st}+30 \mathrm{a}), \mathrm{FN}=$ 106 (Fig. 2A), and multiple Ag-NORs localized at the terminal region of the short arm of chromosome pair 15 and in the long arm of chromosome pair 28, both presenting size heteromorphism between the homologous (Fig 2). C-banding revealed positive heterochromatin predominantly at centromeric regions of most chromosomes, terminal bands in the short arm of the pair 13 and, one of the chromosome pairs 15 and 19, in the long arm of chromosome pairs 26 and 28, and one of the homologous of chromosome pair 4 (Fig. 2B). FISH mapping of $18 \mathrm{~S}$ rDNA probe showed signals in the terminal regions of the short arm of chromosome pairs 13 and 15, and in terminal region of short arm in one chromosome of the pair 14, and the long arm of the pair 28. In addition, 5S rDNA sites were localized in the interstitial region of the short arm of chromosome pairs 5 and 19 and at the terminal region of the short arm of pair 9, 13 and 15 (Fig. 3A). Therefore, there was a synteny (18S/5S rDNA) at the terminal region in the short arm of chromosome pairs 13 and 15. Metaphases of $H$. commersoni subjected to FISH with $H$. commersoni total $\mathrm{C}_{o} \mathrm{t}-1$ DNA probe showed low repetitive DNA accumulation at the terminal and interstitial regions of some chromosomes (Fig. 4A). Hypostomus commersoni metaphases hybridized with $H$. derbyi total $\mathrm{C}_{o} \mathrm{t}-1$ DNA probe presented markers in many chromosomes (Fig. 4B). However, $H$. commersoni chromosomes did not show evident markers using $H$. myersi total $\mathrm{C}_{\mathrm{o}} \mathrm{t}-1 \mathrm{DNA}$ as probe (Fig. $4 \mathrm{C}$ ).

\section{Hypostomus derbyi}

All specimens of $H$. derbyi analyzed presented $2 \mathrm{n}=68$ chromosomes $(12 m+12 s m+10 s t+34 a), F N=102$ (Fig. 2C) and presented single NOR at the terminal region of the short arm of pair 14 (Fig. 2). C-banding pattern showed the heterochromatin at the pericentromeric region of the short arm of the chromosome pair 2 and, at the terminal region of the short arm of pair 14 (Fig. 2D). 18S rDNA sites were localized in the chromosome pair 14, while the 5S rDNA sites were presented at the pericentromeric region of the short arm of the metacentric pair 2 (Fig. 3B). Hypostomus derbyi metaphases were subjected to hybridization with total $\mathrm{C}_{o} \mathrm{t}-1$ probes of $H$. commersoni and $H$. derby total $\mathrm{C}_{o} \mathrm{t}-1$ DNA probe revealing repetitive DNAs at the terminal and interstitial regions of some chromosomes in common (Fig. 4D and E, respectively). In addition, $H$. derbyi metaphases hybridized with $H$. myersi total $\mathrm{C}_{o} \mathrm{t}-1$ probe presented signals predominantly on three chromosome pairs (Fig. 4F).

\section{Hypostomus myersi}

Specimens of $H$. myersi showed $2 \mathrm{n}=74$ chromosomes $(12 \mathrm{~m}+16 \mathrm{sm}+12 \mathrm{st}+34 \mathrm{a})$ and $\mathrm{FN}=$ 114 (Fig. 2E). A single NOR site was detected at the terminal region of the long arm in chromosome pair 32 (acrocentric) and, frequently this site showed a size polymorphism between the homologous regions (Fig. 2). The heterochromatin was localized at centromeric regions of most chromosome pairs. We also detected heterochromatin at terminal regions of the long arm of the pairs 14, 20, 29, 30, 31, 32, 34, 36, and 37. In addition, the short arm of chromosome pair 7 and, and the interstitial region in the long

Braz. Arch. Biol. Technol. v.61: e18180417 2018 
arm of pairs 20, 21, and 23 had heterochromatic regions. A size heteromorphism was observed in heterochromatin block of the chromosome pair 20 in both, males and females. It was visualized an evident overlapping signal between heterochromatic sites and NORs on chromosome pair 32, that show a size heteromorphism (Fig. 2F). 18S rDNA site was localized in chromosome pair 32, while the 5S rDNA site was visualized in the mair 2 (Fig. 3C). Metaphases of $H$. myersi were hybridized with $H$. commersoni total $\mathrm{C}_{o} \mathrm{t}-1$ probe and not showed evident signals in the chromosomes (Fig. 4G). In addition, when metaphases of $H$. myersi were subjected to $H$. derbyi and $H$. myersi total $\mathrm{C}_{o} \mathrm{t}-1$ probes, it was observed repetitive DNA accumulations at terminal and interstitial regions of many chromosomes (Fig. 4H and I, respectively). 


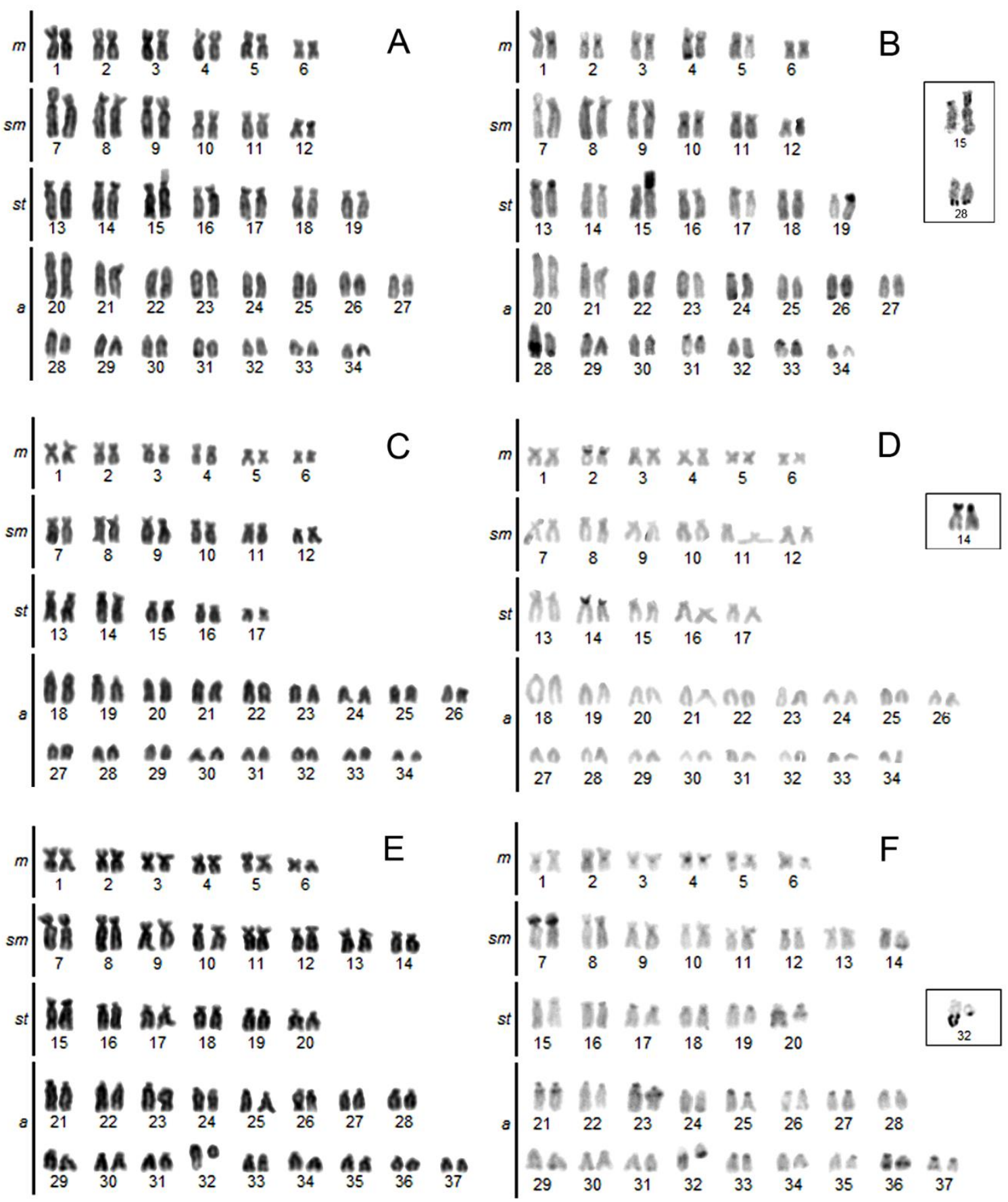

Figure. 2. Karyotypes of H. commersoni $(\mathbf{A}, \mathbf{B}), H$. derbyi $(\mathbf{C}, \mathbf{D})$ and $H$. myersi $(\mathbf{E}, \mathbf{F})$. submitted to Giemsa-stained (A, $\mathbf{C}, \mathbf{E})$ and C-banded chromosomes $(\mathbf{B}, \mathbf{D}, \mathbf{F})$. Chromosome pairs carrying Ag-NORs are boxed. Bar $=10 \mu \mathrm{m}$. 


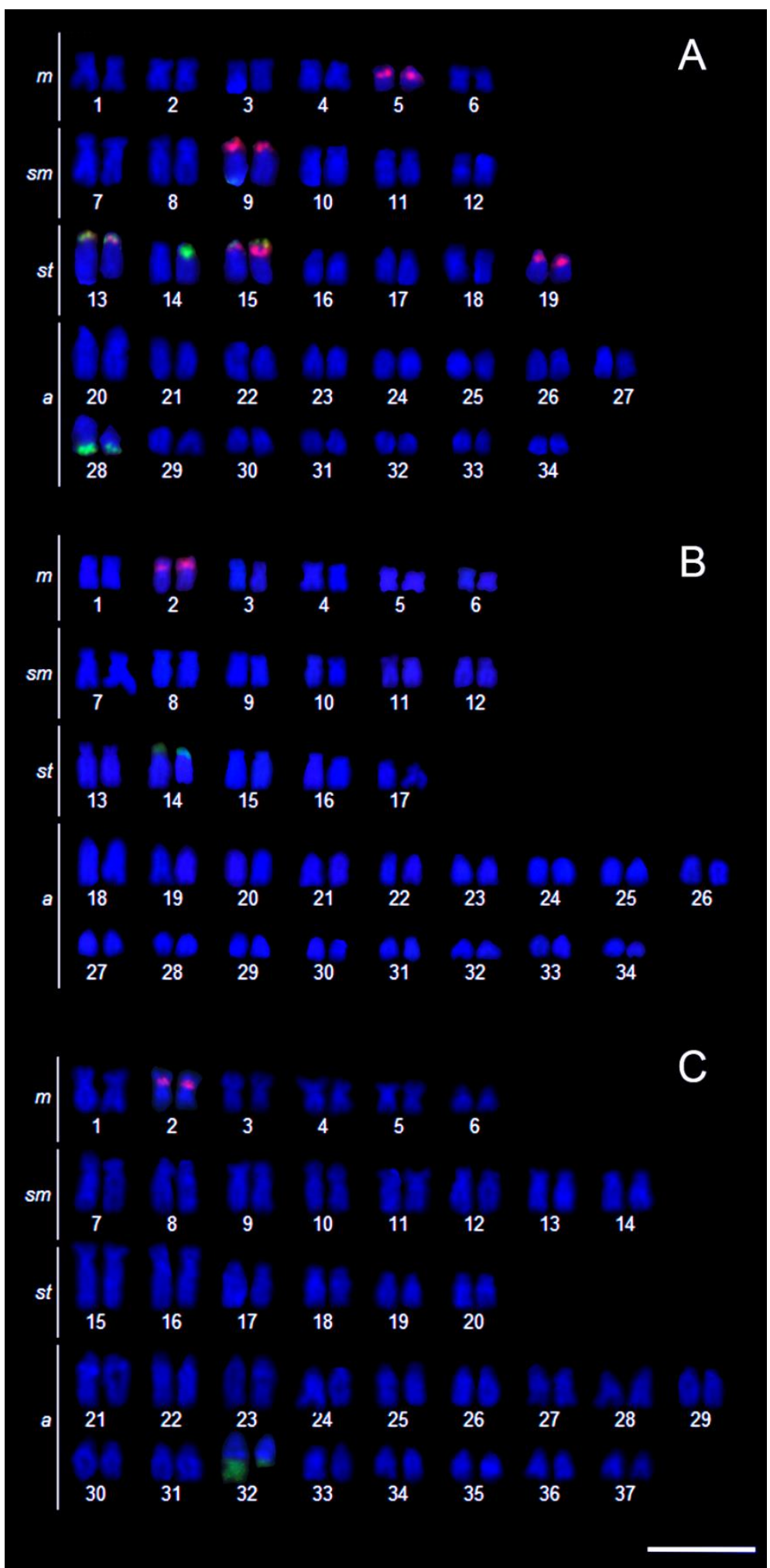

Figure. 3. Double FISH karyotypes with $5 \mathrm{~S}$ rDNA (red markers) and $18 \mathrm{~S}$ rDNA (green markers) probes. (A) Hypostomus commersoni, (B) H. derbyi and, (C) H. myersi. Bar $=10 \mu \mathrm{m}$. 


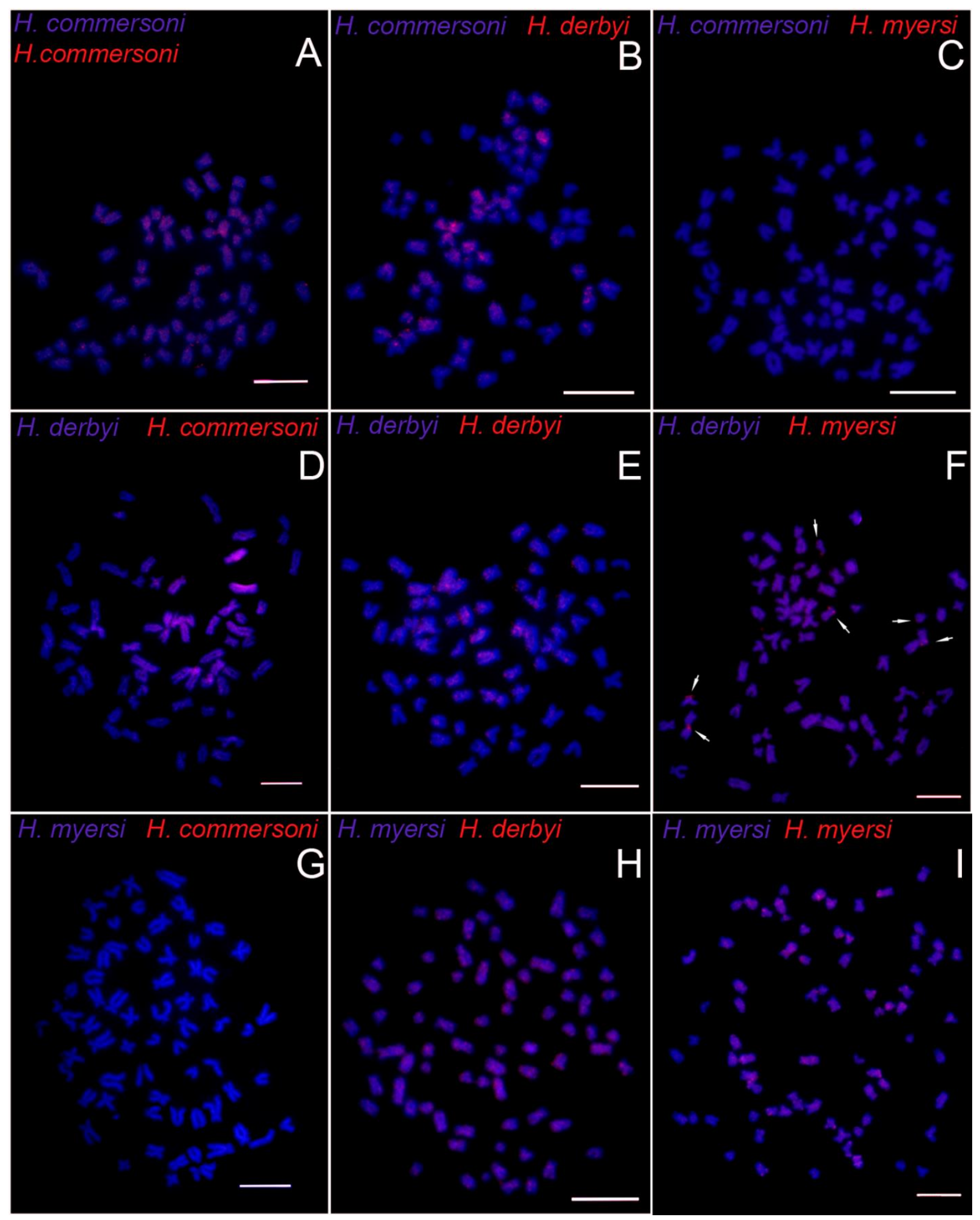

Figure. 4. Metaphases of $H$. commersoni (A-C), H. derbyi (D-F) and $H$. myersi (G-I) after cross-FISH, using $H$. commersoni total $\mathrm{C}_{o} \mathrm{t}-1$ DNA probe $(\mathbf{A}, \mathbf{D}, \mathbf{G}), H$. derbyi total $\mathrm{C}_{o} \mathrm{t}-1$ DNA probe $(\mathbf{B}, \mathbf{E}, \mathbf{H})$ and, H. myersi total $\mathrm{C}_{o} \mathrm{t}-1$ 
DNA probe $(\mathbf{C}, \mathbf{F}, \mathbf{I})$. Red markers correspond to similar repeat DNA chromosomal regions among the species. Bar $=10$ $\mu \mathrm{m}$.

\section{DISCUSSION}

Several cytogenetic studies in Hypostomus revealed a great complexity and diversity of information ${ }^{10-18,40-46}$, showing extensive karyotype variation in this group. Cytogenetic analysis evidenced $2 n=54$ chromosomes as an ancestral characteristic in Loricariidae, since it was reported in the basal genera and in the sister group Trichomycteridae ${ }^{47}$. Karyotype analyses in Hypostomus have allowed well-defined evolutionary trends, as the occurrence of high variation in the $2 \mathrm{n}$, due to chromosomal rearrangements, like centric fissions ${ }^{12-20,40-46}$, which could explain the increased $2 \mathrm{n}$ present in the $H$. commersoni $(2 \mathrm{n}=$ 68 chromosomes $), H$. derbyi $(2 \mathrm{n}=68$ chromosomes $)$ and $H$. myersi $(2 \mathrm{n}=74$ chromosomes).

Chromosome variability in Hypostomus may be assessed by intraspecific variation of $2 \mathrm{n}$, karyotype formula, heterochromatin localization, and number and localization of NORs sites ${ }^{15,17,44}$. Hypostomus plecostomus (Linnaeus, 1758) was described with $2 \mathrm{n}=54$ chromosomes ${ }^{48}$. However, it was considered a misidentification case, once the recent cytogenetic studies in this species has demonstrated $2 n=68$ chromosomes ${ }^{49}$. Thus, in Hypostomus species the $2 \mathrm{n}$ is ranging from 64 chromosomes in Hypostomus sp. Xingu-1, Hypostomus faveolus Zawadzki, Birindelli \& Lima, 2008 and Hypostomus cochliodon Kner, 1854 to 84 chromosomes in Hypostomus perdido Zawadzki, Tencatt \& Froehlich, 2014, cited as Hypostomus sp. 2 Perdido River ${ }^{11-13,50}$. The chromosomal data in this study showed that $2 \mathrm{n}=68$ and different karyotype formulae between $H$. commersoni and $H$. derbyi could be explained by pericentric inversions. Cytogenetic analysis in $H$. derbyi from the Iguaçu river in Curitiba, Paraná state, showed a different karyotype formula ${ }^{51}$ and can suggest chromosomal diversification and cryptic species for $H$. derbyi. In Hypostomus, the number of st/a chromosomes was postulated to be directly proportional to an increase in $2 \mathrm{n}^{13}$. Although $H$. myersi presented small numbers of st/a chromosomes and the highest $2 \mathrm{n}$ among the Hypostomus species analyzed in this work, the pericentric inversions occurred in the chromosomal diversification of the genus, as proposed by Bueno et al. ${ }^{13}$.

In situ localization of ribosomal sites are considered important cytotaxonomic and evolutionary markers for understanding the karyotype differentiation in fishes 10, 22-25. Hypostomus commersoni, $H$. derbyi and $H$. myersi differed in localization and number of chromosome pairs bearing $18 \mathrm{~S}$ rDNA sites. In $H$. derbyi and $H$. myersi, the presence of a single NOR indicated the maintenance of the plesiomorphic condition for Loricariidae 17,47,52-53, while H. commersoni, with multiple NORs, showed a apomorphic condition $10,12,15-16,18,40,45$. A heterochromatin/rDNA association was found to be polymorphic in size between the homologous of the pairs 15 and 28 of $\mathrm{H}$. commersoni and pair 32 of $\mathrm{H}$. myersi, probable due an unequal crossing over and/or amplification of this region, like observed in other Hypostomus ${ }^{12,15,18,41,44}$ and Loricariidae species ${ }^{47,52-53}$.

The heterochromatin/rDNA association visualized in the analyzed species is a common feature in this genus. According to Vicari et al. ${ }^{54}$, the association between NORs and heterochromatin permit the dispersion of the rDNA sites throughout the genome, as visualized for $H$. commersoni, $H$. derby and $H$. myersi, which showed heterochromatin/rDNA associated chromosomal sites. In addition, $H$. commersoni and $H$. myersi presented additional heterochromatic blocks at centromeric, pericentromeric, and terminal regions, when compared to $H$. derby. Hypostomus myersi showed heterochromatic interstitial blocks in the long arms of some st and acrocentric 
chromosomes. The size heteromorphism of the heterochromatin block in pair 20 of the $H$. myersi is due to in cis accumulation of repeat sequences ${ }^{46}$. Interstitial bands have also been observed in Hypostomus regani (Ihering, 1905) ${ }^{18,41}$, Hypostomus topavae (Godoy, 1969) ${ }^{13}$, Hypostomus unae (Steindachner, 1878) ${ }^{43}$ and Hypostomus wuchereri (Günther, 1864) ${ }^{42}$. The pattern of heterochromatin bands at interstitial positions, which are equidistant in relation to the centromere and equilocal in non-homolog chromosomes of the same diploid group, may occur due to chromosome organization in nucleic interphase that would facilitate the transposition these segments ${ }^{55-56}$.

A syntenic chromosomal region of $18 \mathrm{~S}$ and $5 \mathrm{~S}$ rDNAs presenting a size heteromorphism between the homologous chromosomes was observed in $H$. commersoni. This size heteromorphism of $5 \mathrm{~S}$ and $18 \mathrm{~S}$ rDNA clusters may be resulted from unequal crossingover, from the association of repetitive cis-sequences caused by mismatches of repeated DNA units ${ }^{57}$ or, being mediated by the movement of transposable elements (TEs) associated with rDNA ${ }^{58}$. These mechanisms traditionally promote an increase or decrease of the heterochromatin block ${ }^{57}$. Syntenic $5 \mathrm{~S}$ and $18 \mathrm{~S}$ rDNAs observed on chromosome pairs 13 and 15 of $H$. commersoni may be considered a vestige of the ancestral condition of Loricariidae ${ }^{47}$ or a recurrent feature in these species due to an intense movement of rDNA sites, especially when associated with TEs ${ }^{16,58}$. In addition to the syntenic rDNA sites, $H$. commersoni presented multiple sites of $18 \mathrm{~S}$ and $5 \mathrm{~S}$ rDNAs, considered to be derived in Hypostomus, with origin by dispersion of theses sequences throughout the genome, which was confirmed by Traldi et al. ${ }^{10}$

The repetitive fraction obtained by the $\mathrm{C}_{o} \mathrm{t}-1$ reassociation kinetics has been considered an excellent methodology to recover repetitive DNA units, especially TEs, minisatellites, and microsatellites ${ }^{60-61}$. Except the satellite DNA, which is a highly in tandem repetitive sequence and the main heterochromatin marker ${ }^{62-63}$, the TEs, microsatellites, and minisatellites are disperse throughout the genomes, accumulating at heterochromatic regions ${ }^{61,64-65}$. The cross-FISH with DNA $\mathrm{C}_{o} \mathrm{t}-1$ probes of $H$. commersoni, $H$. derbyi, and $H$. myersi showed different distribution of repetitive DNAs among the species analyzed. We observed that $H$. derbyi shares sequences of repetitive DNAs with $H$. commersoni and $H$. myersi, whereas $H$. commersoni and $H$. myersi not possesses shared repeat DNA sequences. These data suggest a higher evolutionary dynamic for the repetitive fraction of the genome of the species $H$. commersoni and $H$. myersi, according to the evolutionary model combined with repetitive units of the genome ${ }^{66}$. Following this model, mutated copies of repetitive DNAs could spread throughout the genome by mechanisms as unequal cross-over ${ }^{59}$ or hitchhiking with TEs, leading to sequence homogenization ${ }^{67}$ in the same genome. However, the effect of these mechanisms, when we compare different genomes, would be the differentiation of repetitive DNA copies, as verified for these species. Chromosome differentiation caused by the movement of repetitive sequences seems to be very important for speciation ${ }^{58,68-70}$. Symonová et al. ${ }^{58}$ provided indirect evidence in which rDNA uses the spreading mechanism of retrotransposons, subsequently affecting recombination rates in genomes, leading to rapid genome divergence in close relationship species. Hence, these extensive genome rearrangements in Hypostomus could be associated with speciation event induced by retrotransposon genome spreading, leading to numeric and structural chromosome diversification.

Cytogenetic data obtained in the present study for the three sympatric and syntopic species of Hypostomus of the middle portion of the Iguaçu River revealed that although $H$. commersoni and $H$. derbyi presented the same diploid number, they diverged in relation to heterochromatic regions and $18 \mathrm{~S}$ and 5S rDNA sites. Hypostomus derbyi and H. myersi, although presenting different diploid number and heterochromatin distribution, shared 
repetitive DNAs and $18 \mathrm{~S}$ and $5 \mathrm{~S}$ rDNA single sites. On the other hand, $H$. commersoni and $H$. myersi were more divergent in all cytogenetic characteristics analyzed.

\section{ACKNOWLEDGEMENTS}

The authors are grateful to the Ministério do Meio Ambiente/ Instituto Chico Mendes de Conservação da Biodiversidade (MMA/ICMBio, SISBIO $n^{\circ}$ : 15117) for authorization to collect the biological samples. This study was funded by CAPES (Coordenação de Aperfeiçoamento de Pessoal de Nível Superior), Fundação Araucária (Fundação Araucária de Apoio ao Desenvolvimento Científico e Tecnológico do Estado do Paraná) and CNPq (Conselho Nacional de Desenvolvimento Científico e Tecnológico).

\section{REFERENCES}

1. Ferraris Jr CJ. Checklist of catfishes, recent and fossil (Osteichthyes: Siluriformes), and catalogue of Siluriform primary types. Zootaxa. 2007; 1418: 1-682.

2. Eschmeyer WN, Fong JD (2018). Species of Fishes by family/subfamily. http://research.calacademy.org/research/ichthyology/catalog/Species>By Family.asp [accessed 29 July 2018].

3. Reis RE, Pereira EHL, Armbruster JAW. Delturinae, a new loricariid catfish subfamily (Teleostei, Siluriformes), with revisions of Delturus and Hemipsilichthys. Zool J Linn Soc. 2006; 147: 277299.

4. Chiachio MC, Oliveira C, Montoya-Burgos JI. Molecular systematic and historical biogeography of the armored Neotropical catfishes Hypoptopomatinae and Neoplecostominae (Siluriformes: Loricariidae). Mol Phylogenet Evol. 2008; 49: 606-617.

5. Cramer CA, Liedke AMR, Bonatto LS, Reis RE. The phylogenetic relationship of the Hypoptopomatinae and Neoplecostominae (Siluriformes: Loricariidae) as inferred from mitochondrial cytochrome c oxidase I sequences. Bull Fish Biol. 2008; 9: 51-59.

6. Cramer CA, Bonatto SL, Reis R. Molecular Phylogeny of the Neoplecostominae and Hypoptopomatinae (Siluriformes: Loricariidae) using multiple genes. Mol Phylogenet Evol. 2011; 59: 43-52.

7. Hollanda Carvalho P, Lima FCT, Zawadzki CH. Two new species of the Hypostomus cochliodon group (Siluriformes: Loricariidae) from the rio Negro basin in Brazil. Neotrop Ichthyol. 2010; 8: 39-48.

8. Zawadzki CH, Weber C, Pavanelli CS. A new dark-saddled species of Hypostomus (Siluriformes: Loricariidae) from the upper rio Paraguay basin. Neotrop Ichthyol. 2010; 8: 719-725.

9. Zawadzki CH, Birindelli JLO, Lima FCT. A new armored catfish species of the genus Hypostomus Lacépède, 1803 (Siluriformes: Loricariidae) from the upper rio Xingu basin, Brazil. Neotrop Ichthyol. 2012; 10: 245-253.

10. Traldi JB, Blanco DR, Vicari MR, Martinez JF, Lui RL, Barros AV, et al. Chromosomal diversity in Hypostomus (Siluriformes, Loricariidae) with emphasis on physical mapping of $18 \mathrm{~S}$ and 5S rDNA sites. Genet Mol Res. 2013; 12: 463-471.

11. Cereali SS, Pompini E, Rosa R, Zawadzki CH, Froehlich O, Giuliano-Caetano L. Karyotype description of two species of Hypostomus (Siluriformes, Loricariidae) of the Planalto da Bodoquena, Brazil. Genet Mol Res. 2008; 7: 583-591.

12. Bueno V, Venere PC, Zawadzki CH, Margarido VP. Karyotypic diversification in Hypostomus Lacépède, 1803 (Siluriformes, Loricariidae): biogeographical and phylogenetic perspective. Rev Fish Biol Fisher. 2013; 23: 103-112.

13. Bueno V, Zawadzki $\mathrm{CH}$, Margarido VP. Trends in chromosome evolution in the genus Hypostomus Lacépède, 1803 (Osteichthyes, Loricariidae): a new perspective about the correlation between diploid number and chromosomes types. Rev Fish Biol Fisher. 2011; 22: 241-250.

Braz. Arch. Biol. Technol. v.61: e18180417 2018 
14. Bueno, V, Konerat JT, Zawadzki CH, Venere PC, Blanco DR, Margarido VP. Divergent chromosome evolution in Hypostominae tribes (Siluriformes: Loricariidae): Correlation of chromosomal data with morphological and molecular phylogenies. Zebrafish. 2018. doi: 10.1089/zeb.2018.1612

15. Rubert M, Zawadzki CH, Giuliano-Caetano L. Cytogenetic characterization of Hypostomus nigromaculatus (Siluriformes: loricariidae). Neotrop Ichthyol. 2008; 6: 93-100.

16. Pansonato-Alves JC, Serrano EA, Utsunomia R, Scacchetti PC, Oliveira C, Foresti F. Mapping five repetitive DNA classes in sympatric species of Hypostomus (Teleostei: Siluriformes: Loricariidae): analysis of chromosomal variability. Rev Fish Biol Fisher. 2013; 23: 477-489.

17. Bueno V, Venere PC, Konerat JT, Zawadzki CH, Vicari MR, Margarido VP. Physical Mapping of the 5S and 18S rDNA in ten species of Hypostomus Lacépède 1803 (Siluriformes: Loricariidae). Evolutionary tendencies in the genus. Sci World J. 2014; 2014: 1-8.

18. Rubert M, da Rosa R, Jerep FC, Bertollo LA, Giuliano-Caetano L. Cytogenetic characterization of four species of the genus Hypostomus Lacépède, 1803 (Siluriformes, Loricariidae) with comments on its chromosomal diversity. Comp Cytogenet. 2011; 5: 397-410.

19. Blanco DR, Vicari MR, Lui RL, Bertollo LAC, Traldi JB, Moreira-Filho O. The role of the Robertsonian rearrangements in the origin of the $\mathrm{XX} / \mathrm{XY} \mathrm{Y}_{2}$ sex chromosome system and in the chromosomal differentiation in Harttia species (Siluriformes, Loricariidae). Rev Fish Biol Fisher. 2013; 23: 127-134.

20. Blanco DR, Vicari MR, Lui RL, Artoni RF, Almeida MC, Traldi JB, et al. Origin of the $\mathrm{X}_{1} \mathrm{X}_{1} \mathrm{X}_{2} \mathrm{X}_{2} / \mathrm{X}_{1} \mathrm{X}_{2} \mathrm{Y}$ sex chromosome system of Harttia punctata (Siluriformes, Loricariidae) inferred from chromosome painting and FISH with ribosomal DNA markers. Genetica. 2014; 142 : 119-126.

21. Blanco DR, Vicari MR, Lui RL, Traldi JB, Bueno V, Martinez JDF, et al. Karyotype diversity and evolutionary trends in armored catfish species of the genus Harttia (Siluriformes: Loricariidae). Zebrafish. 2017; 14: 169-176.

22. Barros AV, Wolski MAV, Nogaroto V, Almeida MC, Moreira-Filho O, Vicari MR. Fragile sites, dysfunctional telomere and chromosome fusions: what is 5S rDNA role? Gene. 2017; 608: 20-27.

23. Primo CC, Glugoski L, Almeida MC, Zawadzki CH, Moreira-Filho O, Vicari MR, et al. Mechanisms of chromosomal diversification in species of Rineloricaria (Actinopterygii: Siluriformes: Loricariidae). Zebrafish. 2017; 14: 161-168.

24. Primo CC, Glugoski L, Vicari MR, Nogaroto V. Chromosome mapping and molecular characterization of the Tc1/Mariner element in Rineloricaria (Siluriformes: Loricariidae). Braz Arch Biol Technol. 2018; 61: e18170623.

25. Glugoski L, Giuliano-Caetano L, Moreira-Filho O, Vicari MR, Nogaroto V. Co-located hAT transposable element and 5S rDNA in an interstitial telomeric sequence suggest the formation of Robertsonian fusion in armored catfish. Gene. 2018; 650: 49-54.

26. Zawadzki CH, Renesto E, Bini LM. Genetic and morphometric analysis of three species of the genus Hypostomus Lacépède, 1803 (Osteichthyes: Loricariidae) from the Rio Iguaçu basin (Brazil). Rev Suisse Zool. 1999; 106: 91-105.

27. Garavelo JC, Britski HA, Zawadzki CH. The cascudos of the genus Hypostomus Lacépède (Ostariophysi: Loricariidae) from the rio Iguaçu basin. Neotrop Ichthyol. 2012; 10: 263-283.

28. Bertollo LAC, Takahashi CS, Moreira-Filho O. Cytotaxonomic considerations on Hoplias lacerdae (Pisces,

Erythrinidae). Braz J Genet. 1978; 2: 103-120.

29. Sumner AT. A simple technique for demonstrating centromeric heterochromatin. Exp Cell Res. 1972; 75: 304-306.

30. Lui RL, Blanco DR, Margarido VP, Moreira-Filho O. First description of B chromosomes in the family Auchenipteridae, Parauchenipterus galeatus (Siluriformes) of the São Francisco River basin (MG, Brazil). Mícron. 2009; 40: 552-559.

31. Howell WM, Black DA. Controlled silver-staining of nucleolus organizer regions with a protective colloidal developer: a 1-step method. Experientia. 1980; 36: 1014-1015.

32. Murray MG, Thompson WF. Rapid isolation of high molecular weight plant DNA. Nucleic Acid Res. 1980; 8: 4321-4326. 
33. Zwick MS, Hanson RE, Mcknight TD, Nurul-Islam-Faridi M, Stelly DM. A rapid procedure for the isolation of Cot-1 DNA from plants. Genome. 1997; 40: 138-142.

34. Wey WH, Zhao WP, Wang LJ, Chen B, Li YC, Song YC. Karyotyping of Brassica napus L. based on Cot-1 DNA banding by fluorescence in situ hybridization. J Integr Plant Biol. 2005; 47 : 1479-1484.

35. Vicari MR, Nogaroto V, Noleto RB, Cestari MM, Cioffi MB, Almeida MC, et al. Satellite DNA and chromosomes in Neotropical fishes: Methods, applications and perspectives. J Fish Biol. 2010; 76: 1094-1116.

36. Hatanaka T, Galetti Jr PM. Mapping of the $18 \mathrm{~S}$ and $5 \mathrm{~S}$ ribosomal RNA genes in the fish Prochilodus argenteus Agassiz, 1829 (Characiformes, Prochilodontidae). Genetica. 2004; 122: 239-244.

37. Martins C, Galetti Jr PM. Chromosomal localization of 5S DNA genes in Leporinus fish (Anostomidae, Characiformes). Chromosome Res. 1999; 7: 363-367.

38. Pinkel D, Straume T, Gray JW. Cytogenetic analysis using quantitative, high-sensitivity, fluorescence hybridization. Proc Natl Acad Sci USA. 1986; 83: 2934-2938.

39. Levan A, Fredga K, Sandberg AA. Nomenclature for centromeric position on chromosomes. Hereditas. 1964; 52: 201-220.

40. Martinez ERM, Zawadzki CH, Foresti F, Oliveira C. Cytogenetic analysis of five Hypostomus species (Siluriformes, Loricariidae). Genet Mol Biol. 2011; 34: 562-568.

41. Mendes-Neto EO, Vicari MR, Artoni RF, Moreira-Filho O. Description of karyotype in Hypostomus regani (Ihering, 1905) (Teleostei, Loricariidae) from the Piumhi river in Brazil with comments on karyotype variation found in Hypostomus. Comp Cytogenet. 2011; 5: 133-142.

42. Bitencourt JA, Affonso PR, Giuliano-Caetano L, Dias AL. Identification of distinct evolutionary units in allopatric populations of Hypostomus cf. wuchereri Günther, 1864 (Siluriformes, Loricariidae): karyotypic evidence. Neotrop Ichthyol. 2011; 9: 317-324.

43. Bitencourt JA, Affonso PR, Giuliano-Caetano L, Dias AL. Heterochromatin heterogeneity in Hypostomus prope unae (Steindachner, 1878) (Siluriformes, Loricariidae) from Northeastern Brazil. Comp Cytogenet. 2011; 5: 329-344.

44. Bitencourt JA, Affonso PRAM, Giuliano-Caetano L, Carneiro PLS, Dias AL. Population divergence and peculiar karyoevolutionary trends in the loricariid fish Hypostomus aff. unae from northeastern Brazil. Genet Mol Res. 2012; 11: 933-943.

45. Endo KS, Martinez ERM, Zawadzki CH, Paiva LRS, Júlio Jr HF. Karyotype description of possible new species of the Hypostomus ancistroides complex (Teleostei: Loricariidae) and other Hypostominae. Acta Scient. 2012; 34: 181-189.

46. Traldi JB, Vicari MR, Blanco DR, Martinez JF, Artoni RF, Moreira-Filho O. First karyotype description of Hypostomus iheringii (Regan, 1908): a case of heterochromatic polymorphism. Comp Cytogenet. 2012; 6: 115-125.

47. Ziemniczak K, Barros AV, Rosa KO, Nogaroto V, Almeida MC, Cestari MM, et al. Comparative cytogenetics of Loricariidae (Actinopterygii: Siluriformes): emphasis in Neoplecostominae and Hypoptopomatinae. Ital J Zool. 2012; 79: 492-501.

48. Muramoto JI, Ohmo S, Atkin NB. On the diploid state of the fish order Ostariophysi. Chromosoma. 1968; 24: 59-66.

49. Oliveira LC, Portela-Castro ALB, Ribeiro MO, Zawadski CH, Dutra ES, Martins-Santos IC. Karyotype structure of Hypostomus cf. plecostomus (Linnaeus, 1758) from Southem Amazon (MT): the occurrence of sex chromosomes (ZZ/ZW) and its evolutionary implications. Genet Mol Res. 2015; 14: 6625-6634.

50. Zawadzki CH, Tencatt LFC, Froehlich O. A new unicuspid-toothed species of Hypostomus Lacépède, 1803 (Siluriformes: Loricariidae) from the rio Paraguai basin. Neotrop Ichthyol. 2014; 12: 97104.

51. Maurutto FAM, Manvailer LFS, Sczepanski TS, Cestari MM, Artoni TF. Cytogenetic characterization of three allopatric species of Hypostomus Lacépède (1803) (Teleostei, Loricariidae). Caryologia. 2012; 65: 340-346. 
52. Becker QMC, Castro RJ, Silva AM, Vizzotto PC. Cytogenetic characterization of two species of Hypostomus (Siluriformes, Loricariidae) from tributaries of the Vermelho river, Upper Paraguay river basin. Biodiversidade. 2014; 13: 2-13.

53. Mariotto S, Centofante L, Vicari MR, Artoni RF, Moreira-Filho O. Chromosomal diversification in ribosomal DNA sites in Ancistrus Kner, 1854 (Loricariidae, Ancistrini) from three hydrographic basins of Mato Grosso, Brazil. Comp Cytogenet. 2011; 5: 289-300.

54. Vicari MR, Artoni RF, Moreira-Filho O, Bertollo LAC. Colocalization of repetitive DNAs and silencing of major rDNA genes. A case report in the fish, Astyanax janeiroensis. Cytogenet Genome Res. 2008; 122: 67-72.

55. John B. The biology of heterochromatin. In: Verma RS, editor. Heterochromatin. Cambridge, Cambridge University Press, 1988.

56. Schweizer D, Loidl J. A model for heterochomatin dispersion and the evolution of C-bands patterns. Chromosomes Today. 1987; 9: 61-74.

57. Pendás AM, Morán P, Garcia-Vasquez E. Multi-chromosomal location of ribossomal RNA genes and heterochromatin association in brown trout. Chromosome Res. 1993; 1: 63-67.

58. Symonová R, Majtánová S, Sember A, Staaks GBO, Bohlen J, Freyhof J, et al. Genome differentiation in a species pair of coregonine fishes: an extremely rapid speciation driven by stressactivated retrotransposons mediating extensive ribosomal DNA multiplications. BMC Evol Biol. 2013; 13: 1-11.

59. Smith GP. Evolution of repeated DNA sequences by unequal crossing-over. Science. 1976; 191: 528-535.

60. Zhang $\mathrm{L}, \mathrm{Xu} \mathrm{C}, \mathrm{Yu}$ W. Cloning and characterization of chromosomal markers from a Cot-1 library of peanut (Arachis hypogaea L.). Cytogenet Genome Res. 2012; 137: 31-41.

61. Schemberger MO, Oliveira JIN, Nogaroto V, Almeida MC, Artoni RF, Cestari MM, et al. Construction and characterization of a repetitive DNA library in Parodontidae (Actinopterygii: Characiformes): A genomic and evolutionary approach to the degeneration of the $\mathrm{W}$ sex chromosome. Zebrafish. 2014; 11: 518-527.

62. Yunis JJ, Yasmineh WG. Heterochromatin, satellite DNA, and cell Function. Science. 1971; 174: 1200-1209.

63. Plohl M, Luchetti A, Meštrovic N, Mantovani B. Satellite DNAs between selfishness and functionality: Structure, genomics and evolution of tandem repeats in centromeric (hetero) chromatin. Gene. 2008; 409: 72-82.

64. Ferreira IA, Martins C. Physical chromosome mapping of repetitive DNA sequences in Nile tilapia Oreochromis niloticus: Evidences for a differential distribution of repetitive elements in the sex chromosomes. Micron. 2008; 39: 411-418.

65. Blanco DR, Lui RL, Vicari MR, Bertollo LAC, Moreira-Filho O. Comparative cytogenetics of giant trahiras Hoplias aimara and H. intermedius (Characiformes, Erythrinidae): chromosomal characteristics of minor and major ribosomal DNA and cross-species repetitive centromeric sequences mapping differ among morphologically identical karyotypes. Cytogenet Genome Res. 2010; 132: 71-78.

66. Zimmer EA, Martin SL, Beverley SM, Kan YW, Wilson AC. Rapid duplication and loss of genes coding for the chains of hemoglobin. Proc Natl Acad Sci U S A. 1980; 77: 2158-2162.

67. Dover GA. Molecular drive: A cohesive mode of species evolution. Nature. 1982; 299: 111-117.

68. Pucci MB, Barbosa P, Nogaroto V, Almeida MC, Artoni RF, Pansonato-Alves JC, et al. Population differentiation and speciation in the genus Characidium (Characiformes: Crenuchidae): effects of reproductive and chromosomal barriers. Biol J Linn Soc. 2014; 111: 541-553.

69. Barbosa P, Pucci MB, Nogaroto V, Almeida MC, Artoni RF, Vicari MR. Karyotype analysis of three species of Corydoras (Siluriformes: Callichthyidae) from southern Brazil: rearranged karyotypes and cytotaxonomy. Neotrop Ichthyol. 2017; 15: e160056.

70. Pucci MB, Nogaroto V, Moreira-Filho O, Vicari MR. Dispersion of transposable elements and multigene families: Microstructural variation in Characidium (Characiformes: Crenuchidae) genomes. Genet Mol Biol. 2018; 41: 585-592. 